\title{
On Cas A, Cassini, Comets, and King Charles
}

\author{
ROBERTO SORIA $^{1,4}$, RICCARDO BALESTRIERI ${ }^{2}$ and YASUYO OHTSUKA ${ }^{3}$ \\ ${ }^{1}$ International Centre for Radio Astronomy Research, Curtin University, GPO Box U1987, Perth, WA 6845, Australia \\ ${ }^{2}$ Via G. Giacomini 87/14, 47890 Città, Repubblica San Marino \\ ${ }^{3}$ British Library, 96 Euston Road, London NW1 2DB, United Kingdom \\ ${ }^{4}$ Corresponding author. Email: roberto.soria@ curtin.edu.au
}

(Received January 7, 2013; Accepted January 9, 2013; Online Publication March 8, 2013)

\begin{abstract}
We re-examine the long-standing problem of the date of the Cassiopeia A supernova (SN), in view of recent claims that it might be the 1630 'noon-star' seen at the birth of King Charles II. We do not support this identification, based on the expected brightness of a Type-IIb SN (too faint to be seen in daylight), the extrapolated motion of the ejecta (inconsistent with a date earlier than 1650), the lack of any scientific follow-up observations, the lack of any mention of it in Asian archives. The origin of the 1630 noon-star event (if real) remains a mystery; there was a bright comet in 1630 June but no evidence to determine whether or not it was visible in daylight. Instead, we present French reports about a fourth-magnitude star discovered by Cassini in Cassiopeia in or shortly before 1671, which was not seen before or since. The brightness is consistent with what we expect for the Cas A SN; the date is consistent with the extrapolated motion of the ejecta. We argue that this source could be the long-sought SN.
\end{abstract}

Keywords: atlases - history and philosophy of astronomy - supernovae: general - supernovae: individual: Cas A

\section{INTRODUCTION}

The young supernova $(\mathrm{SN})$ remnant Cassiopeia $\mathrm{A}$ is one of the best-studied objects in the sky, at all wavelengths; however, the exact date of the $\mathrm{SN}$ event, as well as the nature of the progenitor, is still intriguingly unsolved problems. Finding reliable 17th-century evidence of visual observations would constrain the peak brightness of the event and hence test the currently favoured scenario of a relatively faint Type IIb (Krause et al. 2008), based on the spectral study of scattered light echoes. It would also help modelling the expansion and deceleration of the ejecta, and the proper motion of the compact object (Fesen et al. 2006; Thorstensen, Fesen, \& van den Bergh 2001).

Historians have long debated the possibility that Cas A was the mysterious star ' 3 Cas' observed by John Flamsteed on 1680 August 26 (Gregorian calendar), with arguments in favour of this identification (e.g. Ashworth 1980) because their locations are quite close and no other star exists there today, or against it (e.g. Stephenson \& Green 2002; Green \& Stephenson 2003; Stephenson \& Green 2005a) based on the fact that the discrepancy between the position of 3 Cas and Cas A is still unusually large for Flamsteed's accurate standards. As Stephenson \& Green (2005a) point out, the 10-arcmin discrepancy between 3 Cas and Cas A is much larger than Flamsteed's average error of 23arcsec for the other 20 stars he catalogued on the same night.

In the past couple of years, an alternative suggestion has been presented in several international conferences and press releases ${ }^{1}$ (unfortunately, not in peer-reviewed journals yet) by British astronomer Dr Martin Lunn and American historian Dr Lila Rakoczy, and has become a topic of discussion also among the educated public of amateur astronomers: the possibility that Cas A was the 'noon-star' allegedly visible in the sky on the birthday of the future British king Charles II (1630 May 29 in the Julian calendar, corresponding to June 8 in the Gregorian calendar).

Moreover, over the last few years, ice-core records from Antarctica and Greenland have been studied in search of fossil records of impulsive ionisation events (Dreschhoff \& Laird 2006; Dreschhoff \& Zeller 1990). As suggested by Rood et al. (1979), $\gamma$-rays from $\mathrm{SNe}$ can reach the polar stratosphere and ionise nitrogen and oxygen, which will then combine to form nitrate ions $\left(\mathrm{NO}_{3}^{-}{ }_{3}\right)$. Such nitrates will ultimately be deposited in thin layers of polar ice (Zeller \& Dreschhoff 1995). Two nitrate peaks in the Greenland icecore record were interpreted as signatures of Tycho SN 1572

\footnotetext{
${ }^{1}$ See, for example, www.ras.org.uk/news-and-press/217-news2011/ 1948-nam-4-did-a-supernova-mark-the-birth-of-the-merry-monarch and chandra.harvard.edu/edu/formal/icecore/king_charles.html
} 
and Kepler SN 1604 (Dreschhoff \& Laird 2006). In the same ice record, only two significant nitrate spikes occur in the second half of the 17th century: one around 1667 and another around 1700: Dreschhoff \& Laird (2006) suggested that either of them could be the signature of Cas A. Other spikes were found in the layers corresponding to $1619,1637,1639$, and 1647 (McCracken et al. 2001); no spikes were found for either 1630 or 1680 . However, SN identifications based on nitrate spikes remain a controversial topic (Motizuki et al. 2009; Motizuki, Nakai, \& Takahashi 2010; Risbo, Clausen, \& Rasmussen 1981): gamma-ray bursts, soft gamma repeaters, magnetar flares, and (most importantly) solar proton events can also produce nitrate concentration spikes (Melott $\&$ Thomas 2011), and coastal ice records may be contaminated by nitrates transported through the troposphere from lower latitudes (Motizuki et al. 2010). An argument in favour of a non-solar origin (including a possible $\mathrm{SN}$ ) for the 17thcentury nitrate spikes is the low solar activity during the Maunder Minimum $(\approx 1645-1715)$.

Given the prominence enjoyed by the noon-star claim on the NASA/Chandra public outreach website and on popular astronomy magazines, and the controversial nature of icecore nitrate events, we think it is worth reconsidering this issue. Therefore, in this paper, we discuss whether the identification of a 1630 celestial event with Cas A is scientifically plausible. We then suggest yet another alternative date for the $\mathrm{SN}$, which deserves further investigation.

\section{THE 1630 NOON-STAR: COMET OR SUPERNOVA?}

Comets are the most obvious candidate for a 'new star' unexpectedly appearing in the sky. Indeed, the 1630 star was sometimes called 'a comet' by contemporary writers and pamphleteers (Brown 2010). Lunn \& Rakoczy's argument in favour of a supernova rests strongly on their claim that in 1630 there were no comets bright enough to be visible in daylight ${ }^{2}$. A similar claim was considered and refuted by Lynn (1894), who cites a rather obscure Latin chronicle (Giuseppe Ripamonti's De Peste) describing the scary apparition of two great comets in 1628 and 1630, which were believed to be responsible for an outbreak of bubonic plague in Milan; both comets are also reported by Kronk (1999), based on the same source.

We examined Ripamonti (1640)'s original Latin text (Figure 1): Ripamonti does not directly claim to have seen the 1630 comet: he reports the observation of the "physician and natural philosopher' ${ }^{3}$ Alessandro Tadini (1580-1661). According to Ripamonti (p. 110), Tadini wrote that 'the [comet] star had a scary appearance, even more than usual' ('Sydus fuisse truci ultra solitum etiam facie'), a popular description that usually refers to the size and shape of a comet's tail. 'This

\footnotetext{
${ }^{2}$ http://chandra.harvard.edu/edu/formal/icecore/king_charles.html

${ }^{3}$ This is how he described himself on a memorial stone in the nowdemolished church of Santa Maria della Passarella, in Milan.
}

Ordiebatur philofophantium more Tadinus. difputationem de ea re fuum ab Syderum eriam Coelique argumentis, haud minus nobilis eius. fupremae regionis infpector, quim artifex Medicinae, quae dicta vna eft fcientiarum illarum trium natarum fimul atque adultarum. Aiebat ita, fcripferatque etiam: praecelfife vnguenta Cometem, de quo Sydere femper opinio fuit, tamquam noua quaedam \& magna, \& funefta portendat. Sydus fuiffe truci virra folitum etiam facie. Menfe Iunio, quo maxime tempore, vnguentorum officina illa. Ealuiffe credica eft extitife crinitam eam Stellain : exarfife ad Septentrionem fpectatores fuifie multos: neque dubitaffe diuturna: Coeli.

\section{I I}

Coeli affectatione peritiffimos atque praefagos imminentium homines, quin eius exortu, ea, quae euenere denuntiarentur. Sed \& alium eiufmodi fulgorem emicuiffe prius anno CIO DC xxvirr in cardine dextro ab coitu Saturni, quo non aliud inter Coeli portenta minacius truculentiufue haberetur.

Figure 1. Excerpts from Ripamonti's book De Peste, mentioning a bright and (apparently) scary comet visible from Milan in 1630 June, around the time of King Charles's noon-star. This is the original Latin text mentioned in Lynn (1894).

hairy star appeared in the month of June: it blazed towards the North, many people saw it' ('Mense Junio [...] extitisse crinitam eam stellam: exarsisse ad Septentrionem spectatores fuisse multos'). We checked a later edition of Tadini's book (Tadini 1648), which states: 'A huge comet appeared near the end of June, towards the North, and lasted a long time, seen by many people' ('Apparve nel fine del mese di Giugno una Cometa molto grande verso settentrione et durò molto tempo, vista da più persone'), confirming Ripamonti's account, although 'the end of June' is up to three weeks later than the London sighting.

Based on those records, we agree with Lynn (1894)'s conclusions that there is good evidence for a bright comet in the summer of 1630, but could it be visible in daylight? For that to happen, the head of the comet must have an apparent visual magnitude $m_{v} \lesssim-6$, depending on the size of the comet head and its angular distance from the Sun. Historically, they are rare: we know of fewer than a dozen comets that reached such brightness, and could be seen after sunrise or before sunset. Most but not all of them were sungrazing objects (Sauval 1997). For example, Tycho's comet in 1577 was observed before sunset (Kronk 1999), even though it was not a sungrazing object. Hence, Tadini's observation that the comet blazed 'towards the North' is not inconsistent with 
a daylight brightness; alternatively, it may mean that its tail was pointing towards the north even though its head was near the Sun.

In conclusion, a daylight comet in the summer of 1630 cannot be excluded. The English records are ambiguous on the nature of the object, and there remains a possibility that the whole story is a legend created to glorify the Stuart King, as a sign of divine favour. ${ }^{4}$ In the Italian record, the memory of the event could be distorted by the popular belief that plagues were heralded by comets. Alternatively, implausible as it may seem, there could have been a bright comet and a supernova in the sky at the same time (Cas A would indeed be seen towards the north). To make the situation even more confusing, there was also an almost total solar eclipse ${ }^{5}$ visible from London an hour before sunset on 1630 May 31 Julian calendar (June 10 in the Gregorian calendar), with a magnitude (that is, the fraction of the diameter of the solar disc in eclipse) of $93 \%$, which could have enhanced the perception of astrological significance for the alleged noon-star event reported two days earlier.

\section{JAPANESE RECORDS}

Strom (2002) cites the apparition of a bright object (star or comet) near the Sun, on 1630 August 5, reported by the Chinese Ancient Records of Celestial Phenomena (BAO 1988). Strom (2002)'s favourite interpretation is a sungrazing comet belonging to the Kreutz group, seen at perihelion. ${ }^{6}$ If the comet perihelion was in August, it is unlikely that the same comet could be visible in daylight already in June.

For an independent test on this and other 17th-century events, we decided to search for additional information in the Japanese archives. We looked into the Dai-Nihon Shiryo Unified Database, ${ }^{7}$ the most complete Japanese historical archives. Only the chronological history records between AD 887 and 1622 have been compiled and printed by the Historiographical Institute of the University of Tokyo so far; however, subsequent records will be published in the next few years. We obtained access to yet-unpublished handwritten records covering the rest of the 17 th century. We did find a 'guest star' happening in the year Kan'ei seventh (corresponding to 1630). The annals' entry for the seventh month, eighth day of the Japanese calendar, corresponding to $\mathrm{Au}-$ gust 16, is 'fine weather, a guest star appeared in the East' (Figure 2). We conclude that the Chinese and Japanese records reported the same object, but we do not have enough evidence to identify it with the European event.

We then searched for other possible events in the DaiNihon Shiryo, consistent with an SN in Cassiopeia, between 1630 and 1700 . We did not find any plausible candidates. There are a few objects identified as 'broom stars' (comets),

\footnotetext{
${ }^{4}$ Similar stories are known for other famous rulers. For example, on 1671 August 28, 'the very night of the marriage [between Czar Peter the Great's parents] a brilliant star was perceived quite close to the planet Mars, and was thought by the two astrologers to be a good omen' (Stählin von Storksburg 1788). In 1941, North Korean Dear Leader Kim Jong-il's birth
}

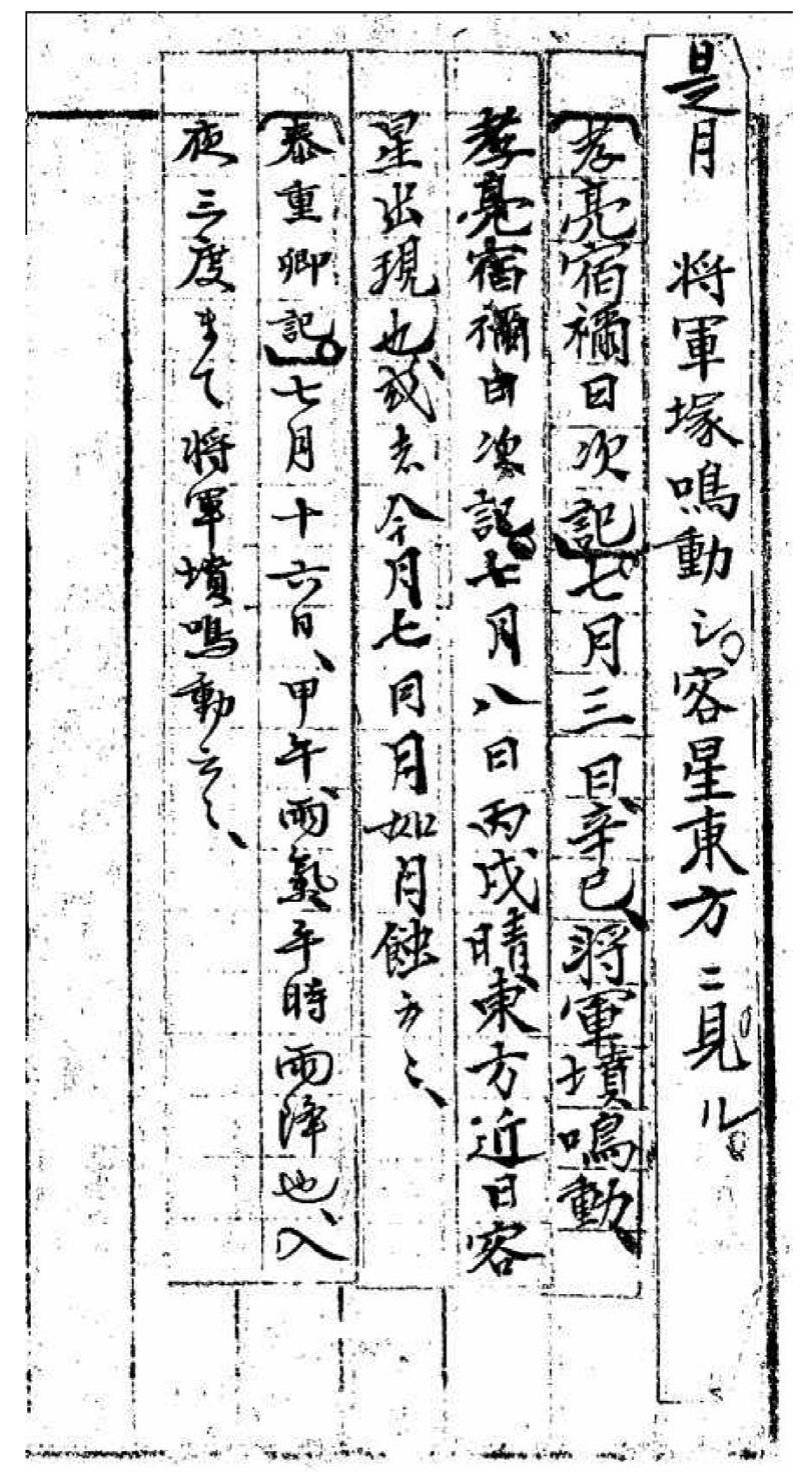

Figure 2. Excerpts from the Dai-Nihon Shiryo (Japanese historical annals), mentioning the appearance of a guest star on 1630 August 16. Image owned by the Historiographical Institute of the University of Tokyo; courtesy of Prof Toru Hoya.

or with corresponding detections in China that are identified as comets, based on their description of appearance and motion in the sky (see also a discussion on the meaning of broom stars in Stephenson \& Green 2005a, 2005b). For example, one seen in China on 1668 March 3-12, and reported in the Dai-Nihon Shiryo entry of 1668 March 8; another one reported in the Chinese records on 1679 September 2 and in the Japanese archives on 1679 August 21.

was allegedly heralded by a bright new star in the heavens and a double rainbow all the way across the sky (e.g. French 2007).

${ }^{5}$ http://eclipse.gsfc.nasa.gov/SEsearch/SEsearchmap.php?Ecl=16300610

${ }^{6}$ Charles II's birth star is mistakenly dated 1648 May 29 in Strom (2002)'s Table 1 and text.

${ }^{7}$ http://www.hi.u-tokyo.ac.jp/english/publication/dainihonshiryo-e.html 
An interesting pair of (likely) separate events is mentioned in the entry for the year Shōō 4th, 5th month, 25th day, which translates as 1647 June 27 in the Gregorian calendar (a year corresponding to a Greenland nitrate spike; McCracken et al. 2001): 'a mysterious bright object flew in the North-Eastern sky; also, a guest star appeared in the West, something I have never seen in my life before'. However, there is no evidence to connect either of these two events (the first of which is perhaps a bright meteor) with Cas A. A bright new object reported to have been seen in the east-north-east sky at dawn on 1661 July 17 could be another sungrazing comet. Similarly, on 1671 November 29, a 'hakki' (a word usually referring to meteors or comets) appeared 'between 7 and 9pm in the Western sky, looking like a bright column of light': but that is obviously not where Cas A would have been located. As for the year 1680 (alleged Flamsteed detection), the only celestial event in the Japanese annals is, as expected, the Great Comet observed in December, well reported in European and North American historical records.

\section{BRIGHTNESS OF TYPE IIb SNe}

A key assumption of the 1630 noon-star identification is that the Cas A SN must have been bright enough to be seen in daylight, as was the Tycho $\mathrm{SN}$ in 1572. We now discuss whether this is the case. Optical spectroscopic studies of the light echo from Cas A have revealed (Krause et al. 2008) that the supernova was of Type IIb. This means that it started as a Type II (with hydrogen lines) but quickly evolved to a Type Ib (no hydrogen lines). This type of events was recognised as a distinct class only a few years ago, and its physical interpretation is still disputed (Claeys et al. 2011). It appears that the progenitor star has only a thin layer of hydrogen left, with a mass of $M_{\mathrm{H}} \sim 0.1-0.5 \mathrm{M}_{\odot}$ when it collapses. In one scenario (Podsiadlowski et al. 1993), the progenitor star fills its Roche lobe in a binary system and transfers most of its hydrogen envelope to its massive companion star. Another scenario (Nomoto et al. 1993) suggests that two massive stars in a binary system actually merge, forming a common envelope, which is mostly but not entirely removed by the energy released by the in-spiralling of the two cores, before the implosion of the merged core. Observationally, a few per cent of core-collapse $\mathrm{SNe}$ are now identified as Type IIb, with wildly discrepant estimates going from $1.5 \%$ to more than $10 \%$ (e.g. Arcavi et al. 2010; Smartt 2009; Smith et al. 2011; Claeys et al. 2011 for a review).

There are 76 SNe identified as Type IIb in the Asiago Catalogue $^{8}$ (Barbon et al. 1999); we also cross-checked the Asiago list with the List of Supernovae web catalogue hosted by the Harvard-Smithsonian Center for Astrophysics ${ }^{9}$. Sixtyeight of them have a host galaxy identification and a discovery or peak visual brightness. We converted the apparent brightness to absolute magnitudes, using the cosmology-corrected

\footnotetext{
${ }^{8}$ Most updated version available online: http://heasarc.gsfc.nasa.gov/ W3Browse/star-catalog/asiagosn.html

${ }^{9}$ cfa-www.harvard.edu/iau/lists/Supernovae.html
}

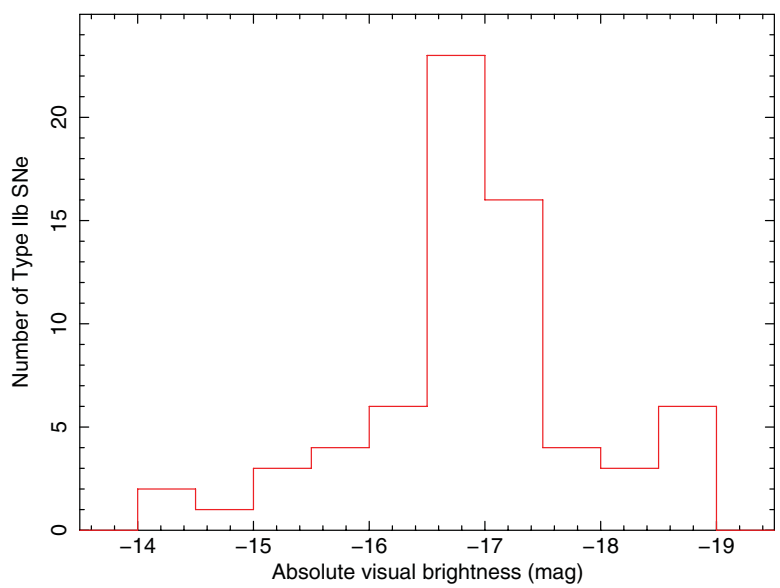

Figure 3. Absolute visual magnitude of the 68 Type IIb $\mathrm{SNe}$ identified since 1993 with a reliable host galaxy identification. Peak brightness was used whenever possible; otherwise, we adopted discovery brightnesses from the Asiago Catalogue.

luminosity distances in NED, ${ }^{10}$ which are based on the 3$\mathrm{K}$ cosmic microwave background frame. We also corrected each source for line-of-sight extinction, using the values from Schlafly \& Finkbeiner (2011). When the optical band is not well defined or specified in the Asiago Catalogue (as is the case for most $\mathrm{SNe}$ discovered by amateur astronomers), we used the extinction in the $V$ band. For a few well-studied $\mathrm{SNe}$ (1993J: Schmidt et al. 1993; 1996cb: Qiu et al. 1999; 2001ig: Bembrick, Pearce, \& Evans 2002; 2008ax: Pastorello et al. 2008; 2011dh: Arcavi et al. 2011), we used more accurate peak brightnesses from individual studies in the literature, rather than the values listed in the Asiago Catalogue, but the difference is generally small and does not affect our general conclusions. We plot the resulting absolute brightness distribution in Figure 3. The distribution is clearly peaked at $-17.5 \lesssim M \lesssim-16.5 \mathrm{mag}$. The tail of the distribution at fainter magnitudes is probably due to objects being discovered past their peak brightness. The small number of sources with $-18.5 \lesssim \mathrm{M} \lesssim-19$ mag may belong to a different sub-class of Type IIb SNe, or may be misclassifications, but that is beyond the scope of this paper. We are also aware that the catalogue contains a mixture of discovery and peak brightnesses, and often non-standard photometric bands or visual estimates; however, the main point of our exercise is simply to show that most Type IIb SNe reach a characteristic absolute brightness of $\sim-17$ mag. (See Richardson, Branch, \& Baron 2006 and Richardson et al. 2002 for the brightness distribution of other classes of $\mathrm{SNe}$, based on the Asiago Catalogue.) The distance of Cas A is $3.4^{+0.3}{ }_{-0.1} \mathrm{kpc}$ (Reed et al. 1995), that is a distance modulus of $=12.7^{+0.2}-0.1$ mag. Adding an extinction $A_{V} \sim 8$ mag (Krause et al. 2008) results in an apparent peak brightness of $m_{V} \sim 3-4$ mag for Cas A, clearly not visible in daylight, and not particularly impressive at night, either.

\footnotetext{
${ }^{10} \mathrm{http}: / /$ ned.ipac.caltech.edu
} 


\section{ADDITIONAL EVIDENCE AGAINST A 1630 CAS A IDENTIFICATION}

Another constraint on the explosion date comes from analyses of the proper motion of the ejecta. Such studies have consistently indicated a date later than 1650. More specifically, Thorstensen et al. (2001) extrapolated an undecelerated convergence date of $1671.3 \pm 0.9$, from a sample of $17 \mathrm{bright}$ knots for which archival imaging data were available over at least 50 years. Using a larger sample of 72 bright and/or compact knots imaged by the Hubble Space Telescope, Fesen et al. (2006) estimated an explosion date of $1671.8 \pm 17.9$ (again, neglecting deceleration). Using instead a subsample of knots from the northwestern limb, which appears to have suffered the least amount of deceleration, Fesen et al. (2006) estimated $1680.5 \pm 18.7$.

Finally, we need to consider a common-sense argument. If the 1630 day-time object was real, and seen by so many common people, it must have caught the attention also of natural philosophers, astrologers, astronomers, mathematicians, and theologians. When a 'new star' (Tycho's SN) appeared in Cassiopeia in 1572 (Brahe 1573), it sparked tremendous interest, with philosophical and scientific discussions about the nature of fixed stars, for the first time unequivocally showing signs of change rather than being perfect and eternal. The new object was immediately reported in sky charts and mentioned in letters and academic treaties. A similar 'new star' event in 1630 (in the same region of sky!) would have been equally well reported, or more, considering the progress of astronomy in the intervening six decades. That was clearly not the case; the lack of interest is consistent with the 1630 event being a more familiar event (meteor or comet).

\section{THE 1671 CASSINI REPORT}

Based on the characteristic age extrapolated from the ejecta, as discussed in Section 5, we decided to focus our search for further clues between about the years 1660 and 1680. By that time, observational astronomy had become more advanced in Europe than in East Asia, and a third-fourth-magnitude object would be more likely to be discovered and catalogued there. If there was one person in the Old Continent specifically interested in the study of variable or new stars, that was Gian Domenico Cassini (1625-1712). Cassini and his collaborator and academic successor Geminiano Montanari (1633-1687) established the first systematic survey of variable stars at the University of Bologna in the late 1660s (after Montanari had serendipitously discovered the variability of Algol in 1667). Cassini moved to Paris on 1669 April 4, invited by King Louis XIV, but continued to pursue this line of research from the newly established Royal Observatory in Paris, which opened in 1671. He was the most renowned and probably most skilled astronomer in Continental Europe at the time, enjoying the same prestige as the British Astronomer Royal Sir John Flamsteed.

\section{LE IOVRNAL DES SCGAVANS. Du Lundy 22. Juin M. DC. LXXI.

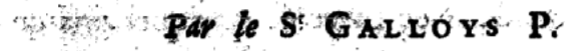

Mais comme le peu d'afleurance qu'on a de l'exactitude du catalogue d'Hipparque, nous donne lieu de croire que plufieurs Etoiles qui n'étoient pas dans ce ca. talogue, ne laiffoient pas d'être dans le Ciel ${ }_{3}$ aúffi faut. il demeurer d'accord que quelques unes de celles qu'on 2 depuis remarquées, n'ont pas toujoürs paru: Car fans. parler icy des Etoiles quel'on a remarquées dans la conftellation de Caffiopé, au col de, la Baleine, a la poitrine du Cygne, 8 daris le Serpentaire, M. Caffini en a découvert plufieurs autres plus petites, de la nouveauté defquelles il y a de grandes prefomptions. Par exem; ple, ilen a obferve vne de $\mathrm{l}_{4}{ }^{\mathrm{e}}$ grandeur \& deux de la $f^{\text {edans }}$ Caffiopec, où il eft certain qu'elles ne fe voyoient pas auparavant, plufieurs Aftronomes ayant exacte. ment compré jufqu'aux plus petites Etoiles de cette conftellation, \& pas un deux n'ayant parlé dé ces trois-lit: Ilen a découvert deuxautres, l'une de la 4 , 8 l'autre de la $\mathrm{s}^{2}$ grandeur, vers le commencement de la conftellation de l'Eridan, où l'on eft encore affuré qu'elles n'ćtoient pas fur la fin de lan 1664 ; parce que

Figure 4. Header and excerpts from Jean Gallois's report on new stars, published on the Journal des Sçavans in 1671. We argue that the fourthmagnitude star in Cassiopeia (never seen before or since) could be the Cas A SN.

Only a minimal part of Cassini's manuscript observation records have been catalogued and published; other information on his work is available from second-hand reports. We searched and found an article written by the natural philosopher and mathematician Jean Gallois (1632-1707), on the 'Journal des Sçavans' (a prestigious French literary and scientific journal founded and edited by Gallois himself), dated Monday 1671 June 22 (Gallois 1671). The topic of the article is variable stars. Gallois writes (p. 35): 'M. Cassini en a découvert plusieurs autres [étoiles] plus petites, de la nouveauté desquelles il y a de grandes presomptions. Par exemple, il en a observé une de la $4^{e}$ grandeur $\&$ deux de la $5^{e}$ dans Cassiopée, où il est certain qu'elles ne se voyoient pas auparavant, plusieurs Astronomes ayant exactement compté jusqu'aux plus petites Etoiles de cette constellation, $\&$ pas un d'eux n'ayant parlé de ces trois-là' (Figure 4). This article is extremely important, because Gallois is very likely reporting what he heard directly from Cassini; the two scientists were close friends and Gallois used to proofread the French language of Cassini's scientific communications (Cassini 1810). In summary, Cassini reported the discovery of a fourth-magnitude star in Cassiopeia in 1671 (together with two fainter ones), a star that was not accounted for in any previous sky chart. 


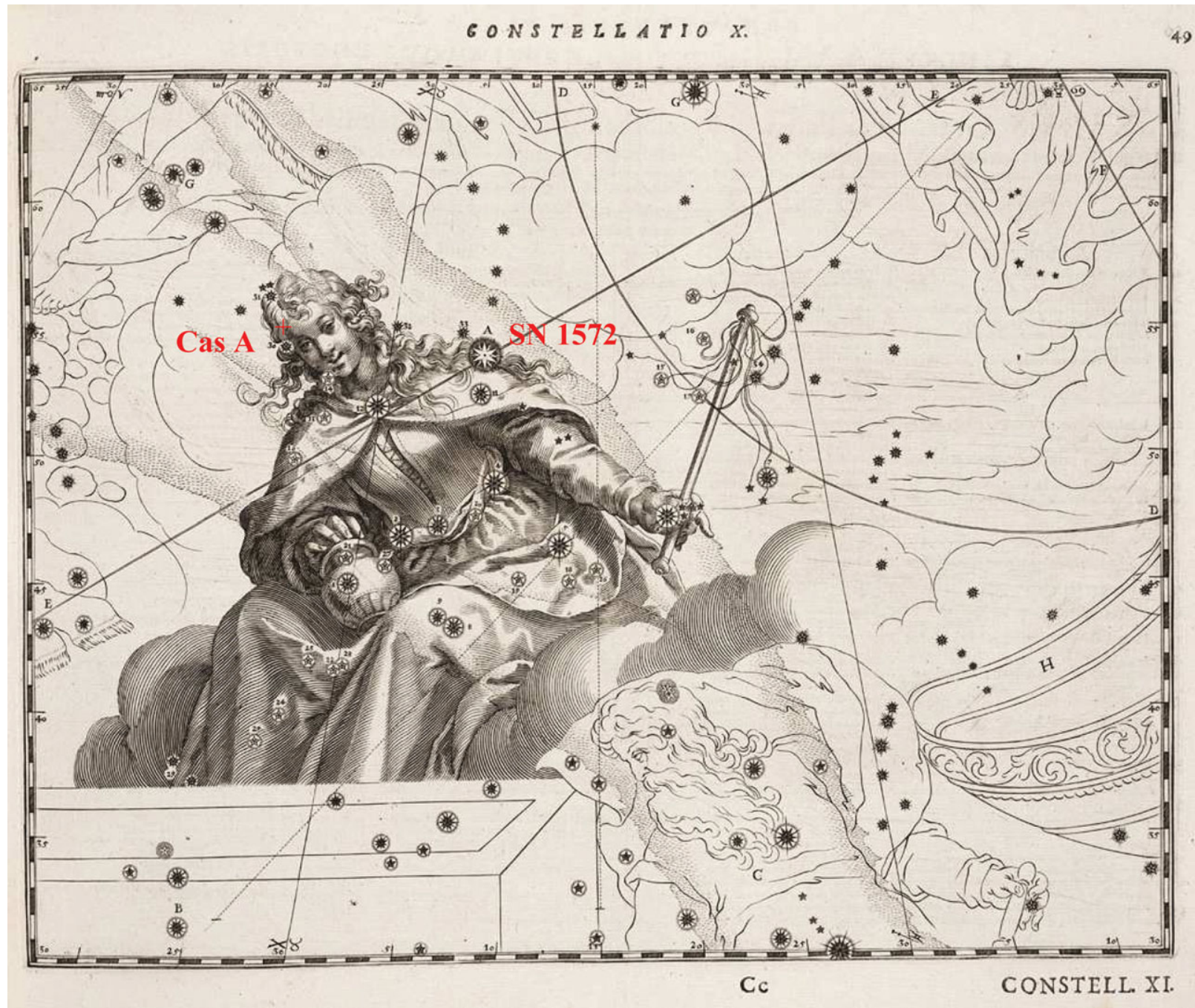

Figure 5. An ancient star map: 'St Mary Magdalen alias Cassiopeia' in Schiller's Coelum Stellatum Christianum (circa 1627); source: the Linda Hall Library of Science, Engineering \& Technology. We overplotted the position of Cas A and Tycho's SN 1572.

This is interesting because we know that all fourthmagnitude stars in Cassiopeia had already been discovered and published in sky charts decades before Cassini's observations. For example, we examined Johann Bayer's Uranometria (Bayer 1603) and compared it with today's Hipparcos catalogue (van Leeuwen 2007). Bayer's chart is complete down to $V=4.83 \mathrm{mag}$. This completeness limit takes into account a couple of binary stars that could not be visually resolved at the beginning of the 17 th century. Note that some of Bayer's stars (in particular, $50 \mathrm{Cas}, V=3.95$ mag) are drawn with the correct location and magnitude in his charts but did not receive a Greek-letter classification: that is routinely the case for stars located outside the 'classical' boundary of a constellation defined by the drawing of its traditional mythological figure. We also checked that Bayer's scale of visual magnitudes corresponds to today's definition; we found that stars classified as 'fourthmagnitude' correspond to $3.5 \leqslant \mathrm{~V} \lesssim 4.5$ mag in the Hipparcos catalogue. Therefore, there should be no ambiguity when Cassini mentions the discovery of a fourth-magnitude star.

Twenty-five years after the publication of Uranometria, Julius Schiller (1580-1627) worked with Johann Bayer (1572-1625) to create a revised and updated stellar atlas (Schiller 1627). Schiller did not simply replace all of the pagan constellations with Christian figures: he added several new stars discovered after the publication of Bayer's charts and refined their positions. We examined Schiller's map of Cassiopeia (Figures 5, 6) and found that it is complete down to $V=4.95 \mathrm{mag}$ (again, allowing for unresolved double stars).

Cassini was certainly well familiar with both Bayer's and Schiller's charts. We find it impossible to believe that the best astronomer in Europe at the time would not know all the dozen-or-so fourth-magnitude stars of Cassiopeia, or that he estimated the wrong brightness for his nouvelle étoile. That is even more implausible considering that Cassiopeia had probably been the most closely monitored region of the sky 


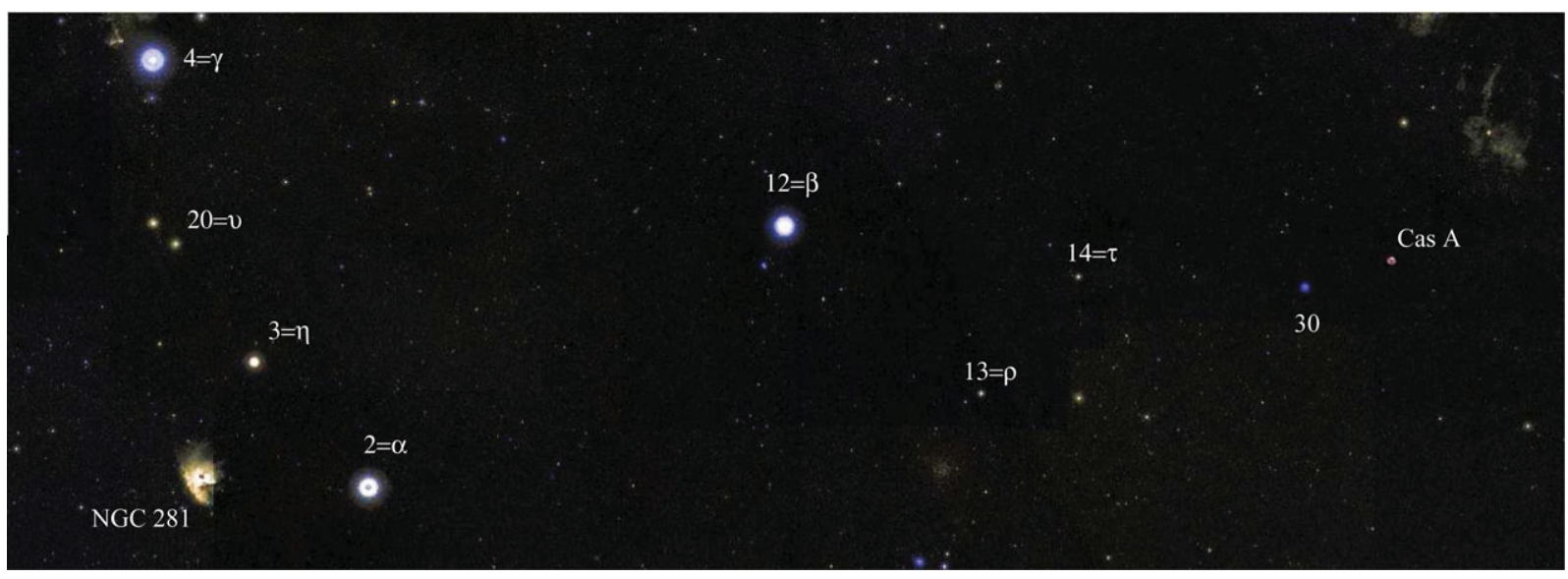

Figure 6. A modern sky map, from GoogleSky (circa 2012), showing the eastern section of Cassiopeia. We labelled some of the stars with Schiller's numbers and Bayer's Greek letters. Size of the image: $13^{\circ} \times 5^{\circ} .5$. North is up and east to the left. Schiller's star Number 30 (also present but not labelled in Bayer's map) is known today as AR Cas, and it may be the object Flamsteed really saw in 1680 (Kamper 1980; Green \& Stephenson 2003).

222 HISTOIRE DEL'ACADEMIEROYALE

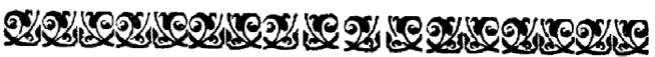 A S T R O N O M I E.}

\section{SUR LES CHANGEMENS DE GRANDEVR apparentes des Etoiles.}

1694. M Onfieur Maraldi, qui fut reçû cette année dans l'Académie, luc le détail de fes Obfervations fur les divers changemens dans la grandeur apparente des étoiles fixes; outre les étoiles qui fe voyoient autrefois, \& qui ont difparu entiérement, ou qui augmentent \& diminuent tour à tour jufqu'à ce qu'on les perde entiérement de vuë, comme celle du col de la Baleine, \& les deux de la conftellation du Cygne, M. Maraldi en a obfervée pluficurs autres qui fubiffent les mêmes changemens de grandeur.

224 HISTOIRE DE L'A CADEMIEROYAL

1694. Dans le Grand Chien l'étoile qui eft à l'oreille droite marquée de la $3^{\mathrm{e}}$ grandeur, \& qui en 1670 . n'étoir prefque plus vifible, eft à préfent de la $4^{\mathrm{e}}$.

Les deux étoilcs de la $2^{\mathrm{e}}$ grandeur dans le Navire, qui font la $3 \mathrm{I}^{\mathrm{e}} \& \mathrm{la} 32^{\mathrm{C}}$, \& qui difparurent du tems des $\mathrm{Ob}-$ fervations de $M$. Montanari, font toûjours invifibles.

Dans Androméde on voir 4 étoiles nouvelles, l'étoile marquée $\mathrm{A}$ dans Bayer, qui avoir difparu fuivant les $\mathrm{Ob}$ - fervations de M. Caffini, eft à préfent vifible.

Dans l'année 1671 . M. Caffini trouva śtoiles nouvelles dans Caffiopée; il n'y en a à préfent que deux qui fubfiftent, les trois autres ont difparu. Mais il y en a trois aurres nouvelles de la $6^{\circ}$ grandeur, une au piedeftal dela chaife, l'autre au ventre, \& la derniére à la poitrine.

M. Maraldi a obfervé encore plufieurs autres étoiles nouvelles, 8 par exemple dans le Pegaze, 3 au-tour des Hyades, 3 dans la Conftellation de la Vierge, \&c. Il remarque que prefque tous les changemens arrivent dans la Voye de Lair,

Figure 7. Header and excerpts from the Histoire de l'Académie Royale des Sciences, reporting on Maraldi's communication in 1694 that some of the new stars found by Cassini in Cassiopeia were no longer visible. since the stunning appearance of SN 1572, and that Cassini was specifically interested in variable stars and therefore in the possibility of a re-appearance of that source. Moreover, Cassiopeia is circumpolar from Europe, so it can be observed all year round. As for the other two new stars observed by Cassini in Cassiopeia in or before 1671, they were of fifth magnitude, at which level the existing charts were not complete; therefore, we do not need to invoke special variability for those.

The next reference we found about Cassini's new stars in Cassiopeia is from the 'Histoire \& Mémoires de l'Académie Royale des Sciences' (Maraldi 1694). We read there that the Italian-French astronomer Giacomo Filippo (Jacques Philippe) Maraldi (1665-1729), inducted into the Académie in 1694 and research staff member at the Paris Observatory since 1687 , presented a report 'On changes of the apparent brightness of stars' ('Sur les changemens de grandeur apparentes des Etoiles'). Maraldi's communication was read to the Académie on 1694 December 4. Secretary Jean-Baptiste Du Hamel (1623-1706) summarised it as such, in the Histoire: 'Dans l'année 1671 M. Cassini trouva 5 étoiles nouvelles dans Cassiopée; il n'y en a à présent que deux qui subsistent, les trois autres ont disparu. Mais il y en a trois autres nouvelles de la $6^{e}$ grandeur, une au piedestal de la chaise, l'autre au ventre, \& la dernière à la poitrine' (Figure 7).

A further mention of the variable stars in Cassiopeia observed by Cassini is found in his son Jacques Cassini (Cassini II)'s Elemens d'astronomie (Cassini 1740), although he appears to summarise the information previously reported by Gallois and Maraldi: 'Outre ces étoiles dont on vient de faire le rapport, mon pere en a découvert plusieurs autres plus petites, qu'on présume être nouvelles. Par exemple, il en a observé une de la quatrieme grandeur, \& deux de la cinquieme, dans la constellation de Cassiopée, où il est certain qu'elles ne se voyoient pau auparavant, n'y ayant aucun Astronome 
qui en ait fait mention, quoiqu'il y en ait eu plusieurs qui ayent exactement compté jusqu'aux plus petites étoiles de cette constellation. En 1671, il trouva cinq nouvelles étolies dans la Cassiopée, dont trois avoient disparu'.

We do not know the coordinates of the transient fourthmagnitude star discovered by Cassini in Cassiopeia, nor of the other variable ones. Cas $\mathrm{A}$ is outside the traditional mythological boundaries of Cassiopeia, located between Cassiopeia and Cepheus: this may explain why its location was not reported more precisely at the time. Moreover, we should not assume (based on the words used by Gallois and Maraldi) that the first observation of the transient star in Cassiopeia occurred precisely in the first half of 1671. Cassini was known to observe his targets meticulously for years, sometimes, before reporting a result or a new discovery. This caveat is important in view of the nitrate spike detected in the 1667 ice layers. On the other hand, on 1668 July 2, the Journal des Sçavans reported on the 'Apparizioni celesti dell'anno 1668 osservate in Bologna da Gio. Domenico Cassini Astronomo dello studio publico' (Gallois 1668), in which other variable stars are mentioned, but not those in Cassiopeia.

To make further progress, we need to access and search through the original records of Cassini's observations, especially those between 1669 and 1671. Such documents are still kept in the archives of the Paris Observatory, and have never been catalogued or scanned. We are negotiating the possibility of accessing those archive in Paris for further research. Hopefully, we will report on this in follow-up work. But for now, we can already propose that Cassini's 1671 reported observation of a fourth-magnitude transient star in Cassiopeia is at least as strong a candidate for Cas A as Flamsteed's 1680 observation.

\section{CONCLUSIONS}

We examined recent claims that the Cas A SN might be identified with a 1630 'noon-star' reported in the English literature. We strongly disfavour this possibility, based on the expected brightness of a Type IIb SN (too faint to be seen in daylight), the extrapolated motion of the ejecta (inconsistent with any explosion date earlier than at least 1650), and the lack of any scholarly reference to the event. We detail strong evidence that there was a bright comet in 1630 June, but we found no evidence to determine whether it could be visible in daylight. We also found no record of day-time guest stars or broom stars consistent with a 1630 Cas A SN in the Japanese archives. Based on the motion of the ejecta, we focused our search for the Cas A progenitor to the years between about 1660 and 1680, and to the astronomers who would have been most likely to notice it: Gian Domenico Cassini and his collaborators, who were doing pioneering work on variable stars. We found a report about a fourth-magnitude star (that is, with the brightness expected for the Cas A SN) discovered by Cassini in Cassiopeia in or shortly before 1671 (the same epoch inferred for the event by Thorstensen et al. 2001), which was not seen before or since. We argue that this source could be the long-sought SN, but further research in the original observing logs (kept at the Paris Observatory) is needed to determine the discovery date and coordinates of the transient Cassiopeia object observed by Cassini.

\section{ACKNOWLEDGMENTS}

We thank Fabrizio Bònoli, Valeria Zanini, Suzanne Débarbat, Nicola Masetti, Naomi Mockford, and an anonymous referee for their suggestions and comments. We thank Toru Hoya and Hidenori Ouchi for their invaluable help with the Japanese records at the Historiographical Institute of the University of Tokyo.

\section{REFERENCES}

Arcavi, I., et al. 2010, ApJ, 721, 777

Arcavi, I., et al. 2011, ApJ, 742, L18

Ashworth, W. B. 1980, JHA, 11, 1

Barbon, R., Buondí, V., Cappellaro, E., \& Turatto, M. 1999, A\&AS, 139,531

Bayer, J. 1603, in Uranometria: Omnium asterismorum continens schemata, nova methodo delineata, aereis laminis expressa, (Augsburg, Germany: C. Mangus)

Beijing Astronomical Observatory [BAO] (Chief editor) 1988, Zhong guo gu dai tian xiang ji lu zong ji (Nanjing: Jiangsu Science and Technology Publishing)

Bembrick, C., Pearce, A., \& Evans, R. 2002, IAUC, 7804, 2

Brahe, T. 1573, in De nova et nullius aevi memoria prius visa stella iam pridem anno a nato Christo 1572 , mense Novembri primum conspecta, contemplatio mathematica (Copenhagen: Laurentius Benedictus)

Brown, M. A. 2010, in The Pleiadic Age of Stuart Poesie: Restoration Uranography, Dryden's Judicial Astrology, and the Fate of Anne Killigrew, English theses (Georgia State University), 49

Cassini, J. [Cassini II] 1740, in Elemens d'astronomie (Paris: Imprimerie Royale), 72

Cassini IV, J.-D. 1810, in Mémoires pour servir à l'Histoire des Sciences et à celle de l'Observatoire Royal de Paris, suivis de la vie de J.-D. Cassini, écrite par lui-même, et des éloges de plusieurs Académiciens morts pendant la Révolution (Paris: Bleuet), 289

Claeys, J. S. W., de Mink, S. E., Pols, O. R., Eldridge, J. J., \& Baes, M. 2011, A\&A, 528, 131

Dreschhoff, G. A. M., \& Laird, C. M. 2006, AdSpRes, 38, 1307

Dreschhoff, G. A. M., \& Zeller, E. J. 1990, Sol. Phys., 127, 333

Fesen, R. A., et al. 2006, ApJ, 645, 283

French, P. 2007, in North Korea: The Paranoid Peninsula: A Modern History (London: Zed Books), 57

Gallois, J. 1668, 'Apparizioni celesti dell'anno 1668 osservate in Bologna da Gio. Domenico Cassini Astronomo dello studio publico', J. Sçavans, 57

Gallois, J. 1671, 'Observation d'une étoile nouvellement découverte proche la Constellation du Cygne', J. Sçavans, 32

Green, D. A., \& Stephenson, F. R. 2003, LNP, 598, 7

Kamper, K. W. 1980, Obs, 100, 3

Krause, O., Birkmann, S. M., Usuda, T., Hattori, T., Goto, M., Rieke, G. H., \& Misselt, K. A. 2008, Sci, 320, 1195 
Kronk, G. W. 1999, Cometography: A Catalog of Comets, Vol. 1: Ancient-1799 (Cambridge: Cambridge University Press)

Lynn, W. T. 1894, Obs, 17, 272

Maraldi, G. F. 1694, "Sur les changemens de grandeur apparente des Etoiles", in Histoire \& Mémoires de l'Académie Royale des Sciences. Depuis 1666 jusq'à 1699, 2, 222

McCracken, K. G., Dreschhoff, G. A. M., Zeller, E. J., Smart, D. F., \& Shea, M. A. 2001, J. Geophys. Res., 106, 21599

Melott, A. L., \& Thomas, B. C. 2011, Astrobiology, 11, 343

Motizuki, Y., Nakai, Y., \& Takahashi, K. 2010, Highlights Astron., 15,630

Motizuki, Y., et al. 2009, arXiv:0902.3446

Nomoto, K., et al. 1993, Natur, 364, 507

Pastorello, A. 2008, MNRAS, 389, 955

Podsiadlowski, P., Hsu, J. J. L., Joss, P. C., \& Ross, R. R. 1993, Natur, 364, 509

Qiu, Y., Li, W., Qiao, Q., \& Hu, J. 1999, AJ, 117, 736

Reed, J. E., Hester, J. J., Fabian, A. C., \& Winkler, P. F. 1995, ApJ, 440, 706

Richardson, D., Branch, D., \& Baron, E. 2006, AJ, 131, 2233

Richardson, D., Branch, D., Casebeer, D., Millard, J., Thomas, R. C., \& Baron, E. 2002, AJ, 123, 745

Ripamonti, G. 1640, in 'De peste quae fuit anno MDCXXX' (Mediolani: Malatestas, Regios ac Ducales Typographos), 110, 273

Risbo, T., Clausen, H. B., \& Rasmussen, K. L. 1981, Natur, 294, 637

Rood, R. T., Sarazin, C. L., Zeller, E. J., \& Parker, B. C. 1979, Natur, 282, 701
Sauval, J. 1997, Longest Visibility of Ancient Comets, unpublished report available online at http://www.eso.org/public/ events/astro-evt/hale-bopp/comet-hale-bopp-may15-js.html

Schiller, J. 1627, in Coelum Stellatum Christianum', (Augsburg, Germany: A. Apergerus)

Schlafly, E. F., \& Finkbeiner, D. P. 2011, ApJ, 737, 103

Schmidt, B. P., et al. 1993, Natur, 364, 600

Smartt, S. J. 2009, ARA\&A, 47, 63

Smith, N., Li, W., Filippenko, A. V., \& Chornock, R. 2011, MNRAS, 412,1522

Stählin von Storcksburg, J. 1788, in Original Anecdotes of Peter the Great: Collected from the Conversation of Several Persons of Distinction at Petersburgh and Moscow, (London: J. Murray, J. Sewell, \& W. Creech), 395

Stephenson, F. R., \& Green, D. A. 2002, in Historical Supernovae and Their Remnants, International Series in Astronomy and Astrophysics (Oxford: Clarendon Press), 5

Stephenson, F. R., \& Green, D. A. 2005a, JHA, 36, 217

Stephenson, F. R., \& Green, D. A. 2005b, ASPC, 342, 63

Strom, R. 2002, A\&A, 387, L17

Tadini, A. 1648, in Ragguaglio dell'Origine et Giornali Successi della Gran peste Contagiosa Venefica et Malefica seguita in Milano e suo Ducato dall'anno 1629 al 1631', (Milan: F. Ghisolfi)

Thorstensen, J. R., Fesen, R. A. \& van den Bergh, S. 2001, AJ, 122, 297

van Leeuwen, F. 2007, A\&A, 474, 653

Zeller, E. J., \& Dreschhoff, G. A. M. 1995, Geophys. Res. Lett., 22, 2521 